ARTICLE

https://doi.org/10.1038/s41467-019-09449-7

\title{
Critical role of formaldehyde during methanol conversion to hydrocarbons
}

Yue Liu (1D ' ${ }^{1}$, Felix M. Kirchberger ${ }^{1}$, Sebastian Müller ${ }^{1}$, Moritz Eder ${ }^{1}$, Markus Tonigold ${ }^{2}$, Maricruz Sanchez-Sanchez ${ }^{1} \&$ Johannes A. Lercher ${ }^{1}$

Formaldehyde is an important intermediate product in the catalytic conversion of methanol to olefins (MTO). Here we show that formaldehyde is present during MTO with an average concentration of $\sim 0.2 \mathrm{C} \%$ across the $\mathrm{ZSM}-5$ catalyst bed up to a $\mathrm{MeOH}$ conversion of $70 \%$. It condenses with acetic acid or methyl acetate, the carbonylation product of $\mathrm{MeOH}$ and $\mathrm{DME}$, into unsaturated carboxylate or carboxylic acid, which decarboxylates into the first olefin. By tracing its reaction pathways of ${ }^{13} \mathrm{C}$-labeled formaldehyde, it is shown that formaldehyde reacts with alkenes via Prins reaction into dienes and finally to aromatics. Because its rate is one order of magnitude higher than that of hydrogen transfer between alkenes on ZSM-5, the Prins reaction is concluded to be the major reaction route from formaldehyde to produce dienes and aromatics. In consequence, formaldehyde increases the yield of ethene by enhancing the contribution of aromatic cycle.

\footnotetext{
${ }^{1}$ Department of Chemistry and Catalysis Research Center, Technische Universität München, Lichtenbergstr. 4, 85747 Garching, Germany. ${ }^{2}$ Clariant Produkte (Deutschland) GmbH, Waldheimer Straße 13, 83052 Bruckmühl, Germany. These authors contributed equally: Yue Liu, Felix M. Kirchberger Correspondence and requests for materials should be addressed to M.S.-S. (email: m.sanchez@tum.de) or to J.A.L. (email: johannes.lercher@tum.de)
} 
T he conversion of methanol to hydrocarbons (MTH) is considered as a promising route of converting gas and coal to fuels and chemicals via methanol ${ }^{1-3}$. By adjusting catalysts and reaction conditions, the product distribution shifts from gasoline-range (methanol to gasoline; MTG) to lower olefinrange products (methanol to olefins; MTO) ${ }^{1}$. As a consequence, methanol conversion has been commercialized in different variants 1,4 . The central mechanism consists of two catalytic cycles $^{5-7}$ interconverting surface species (hydrocarbon pool) ${ }^{8,9}$. One is called olefin-cycle and it is dominated by methylation of light alkenes, followed by cracking of the larger alkenes. The other is called aromatic-cycle catalyzing methylation of aromatic molecules followed by cracking of a side chain. The fast propagation of these two cycles is responsible for the autocatalytic nature of the MTH reaction. The relative contribution of each cycle depends on the local concentrations of hydrocarbon species within the zeolite ${ }^{10}$.

A mechanistic description focused solely on hydrocarbons as key compounds may lead, however, to a rather incomplete description of the interlinked processes. As far back as 1984, evidence of formaldehyde formation under the conditions of methanol conversion was given. Kubelková et al. ${ }^{11}$ reported formaldehyde and methane formed by methanol disproportionation on $\mathrm{H}-\mathrm{ZSM}-5$ at $670 \mathrm{~K}$ and low methanol pressures (1-3 Pa). Hutchings et al. observed methane before $\mathrm{C}_{2+}$ hydrocarbons formation at low methanol coverage, supporting these results ${ }^{12,13}$. On the basis of these results a methane-formaldehyde mechanism leading to first $\mathrm{C}-\mathrm{C}$ bond was proposed by Tajima et al. ${ }^{14}$ In spite of these first reports, formaldehyde in methanol conversion did not attract much attention until recently. Theoretical calculations ${ }^{15-17}$ and dedicated experiments ${ }^{15,17,18}$ showed possible pathways forming the first $\mathrm{C}-\mathrm{C}$ bond and first olefin from $\mathrm{HCHO}$ in a subtle interplay with Brønsted acid and extra-framework $\mathrm{Al}$ sites. Experimental observations of strong deactivation in presence of $\mathrm{HCHO}^{19,20}$ and of the $\mathrm{O}$-containing surface species, were attributed to reaction products of $\mathrm{HCHO}$, strongly adsorbed on the zeolite acid sites ${ }^{21-23}$. While always being present during MTO conversion at least in very low concentrations, it promotes the formation of non-olefinic byproducts ${ }^{24,25}$ and accelerates deactivation ${ }^{19-21,26,27}$. The recognition of the importance of $\mathrm{HCHO}$ in MTO makes it imperative to quantify its concentration in the reaction and distribution over the catalyst bed. However, the very low concentration of $\mathrm{HCHO}$ and its high reactivity on acid sites set obstacles in such quantitative studies.

Generation of HCHO under MTO conditions occurs via several pathways, including hydride transfer between two methanol molecules $(\operatorname{Rxn} 1)^{10-13,15}$, thermal or reactor-wall catalyzed decomposition of methanol ( $\mathrm{Rxn} 2)^{18}$ and hydrogen transfer from methanol to alkenes on Lewis acid sites (LAS) $(\mathrm{Rxn} 3)^{24}$.

$$
\begin{gathered}
2 \mathrm{CH}_{3} \mathrm{OH} \rightarrow \mathrm{HCHO}+\mathrm{CH}_{4}+\mathrm{H}_{2} \mathrm{O} \\
\mathrm{CH}_{3} \mathrm{OH} \rightarrow \mathrm{HCHO}+\mathrm{H}_{2} \\
\mathrm{CH}_{3} \mathrm{OH}+\text { Alkene } \rightarrow \mathrm{HCHO}+\text { Alkane }
\end{gathered}
$$

The present study quantifies the concentration level of $\mathrm{HCHO}$ and its distribution along the catalyst bed in MTO, and explores the role of formaldehyde as intermediate in two critical stages of methanol conversion. We examine rigorously the participation of formaldehyde in the formation of the first olefinic product on the one hand and its impact on product distribution and deactivation of an H-ZSM-5 catalyst on the other hand. Insight into these elementary steps will help to tailor catalysts to higher alkene selectivity, while extending the useful lifetime of the catalysts.
Table 1 Stream composition in methanol reaction over $\mathbf{H}$ ZSM-5 at a conversion of $0.24 \%^{a}$

\begin{tabular}{lll} 
Effluent molecules & Effluent composition (C\%) & Selectivity (C\%) \\
\hline $\mathrm{MeOH}+\mathrm{DME}$ & 99.76 & \\
$\mathrm{CH}$ & 0.12 & 50 \\
$\mathrm{HCHO}$ & 0.06 & 25 \\
$\mathrm{CO}+\mathrm{CO}_{2}$ & $0.06^{\mathrm{b}}$ & 25 \\
$\mathrm{C}_{2} \mathrm{H}_{4}$ & $<0.01$ & $<4$ \\
$\mathrm{H}_{2}$ & $<0.01(\mathrm{H} \%)^{\mathrm{c}}$ & -
\end{tabular}

aConditions: $475^{\circ} \mathrm{C}$, DME 90 mbar, H-ZSM5 (Si/Al 90 steamed), W/F $0.076 \mathrm{~h} \cdot \mathrm{g}_{\text {(cat) }} \cdot \mathrm{mol}_{\mathrm{C}}{ }^{-1}$ bestimated based on $\mathrm{C}$ balance

cBelow detection limit

\section{Results}

Formaldehyde detection in MTO. Methanol decomposes into $\mathrm{HCHO}$ under typical reaction conditions employed in this study (MTO conditions) $)^{18,21-24}$. The concentration of the intermediately formed $\mathrm{HCHO}$ has not been discussed until now, because the combination of low concentrations and high reactivity makes this very challenging under typical reaction conditions reported. To achieve quantification, we turn to very low conversions. A blank test shows only a conversion of $\mathrm{MeOH}$ to $0.01 \mathrm{C} \%$ methane and $0.01 \mathrm{C} \% \mathrm{HCHO}$, while with $\mathrm{H}-\mathrm{ZSM}-5$ a higher conversion was observed. Table 1 shows a typical effluent composition at a methanol ( $+\mathrm{DME})$ conversion of only $0.24 \mathrm{C} \%$ on $\mathrm{H}-\mathrm{ZSM}-5$ at $475^{\circ} \mathrm{C}$. Methane is the dominant product with a yield of $0.12 \mathrm{C} \%$, and $\mathrm{HCHO}$ has a yield of $0.06 \mathrm{C} \%$. The rest are $\mathrm{CO}$ and $\mathrm{CO}_{2}$, with a yield of $0.06 \mathrm{C} \%$. The olefin yield was very low at these conditions, and only a trace concentration of ethene, below $0.01 \mathrm{C} \%$, was detected. The amount of $\mathrm{H}_{2}$ was below the detection limit. This shows that $\mathrm{MeOH} / \mathrm{DME}$ is converted to $\mathrm{HCHO}$ with a selectivity as high as $25 \%$ before alkenes are formed in appreciable amounts and the hydrocarbon pool has evolved. In Fig. 1 it is shown that by increasing the residence time the yield of $\mathrm{HCHO}$ increased to a yield maximum of $0.27 \mathrm{C} \%$ at $\sim 20 \%$ conversion of $\mathrm{MeOH}$, and then it decreased gradually with higher conversions to levels below the detection limit. These results directly establish the presence of $\mathrm{HCHO}$ in $\mathrm{H}-\mathrm{ZSM}-5$ under MTO reaction conditions and its concentration evolution with the conversion of $\mathrm{MeOH}$. We investigate next in which steps of the complex reaction network of methanol to olefins does $\mathrm{HCHO}$ participate.

Having established that $\mathrm{HCHO}$ is a main product at low $\mathrm{MeOH} / \mathrm{DME}$ conversions before alkenes are detected in significant concentrations in the products, we use surface reactions of adsorbed $\mathrm{MeOH}$ on $\mathrm{H}-\mathrm{ZSM}-5$ to better understand the possible reaction pathways. Figure 2 shows the evolution of gaseous products and surface species from H-ZSM5 saturated with 3 mbar $\mathrm{MeOH}$ as a function of temperature. With increasing temperature, $\mathrm{MeOH}$ desorption reached a maximum at $120^{\circ} \mathrm{C}$, while DME had maximum at $180^{\circ} \mathrm{C}$ with formation extending to $300^{\circ} \mathrm{C}$ (Fig. 2a). Decomposition and disproportionation products from $\mathrm{MeOH}$, including $\mathrm{CH}_{4}, \mathrm{HCHO}$ and $\mathrm{CO}$, were detected from 220 to $400{ }^{\circ} \mathrm{C}$ with maxima at $290{ }^{\circ} \mathrm{C}$, forming a mixture of $\mathrm{C}_{1}$ species. Alkenes appeared at $300{ }^{\circ} \mathrm{C}$ and reached a maximum at $380^{\circ} \mathrm{C}$. This agrees with previously reported results, linking the formation of first $\mathrm{C}-\mathrm{C}$ bond in $\mathrm{MTH}$ to the presence of small concentrations of $\mathrm{CO}^{18}$. In a recent report, $\mathrm{Wu}$ et al. observed a simultaneous appearance of ethene and propene with $\mathrm{CH}_{4}$ and $\mathrm{HCHO}$, hence proposing a direct $\mathrm{C}-\mathrm{C}$ formation from $\mathrm{MeOH}$, DME, surface methoxy or trimethyloxonium ion ${ }^{28,29}$. While we cannot establish the experimental differences, our present study unequivocally identified that olefin appeared after $\mathrm{CH}_{4}, \mathrm{HCHO}$ and $\mathrm{CO}$ strongly suggesting that olefin formation follows a 


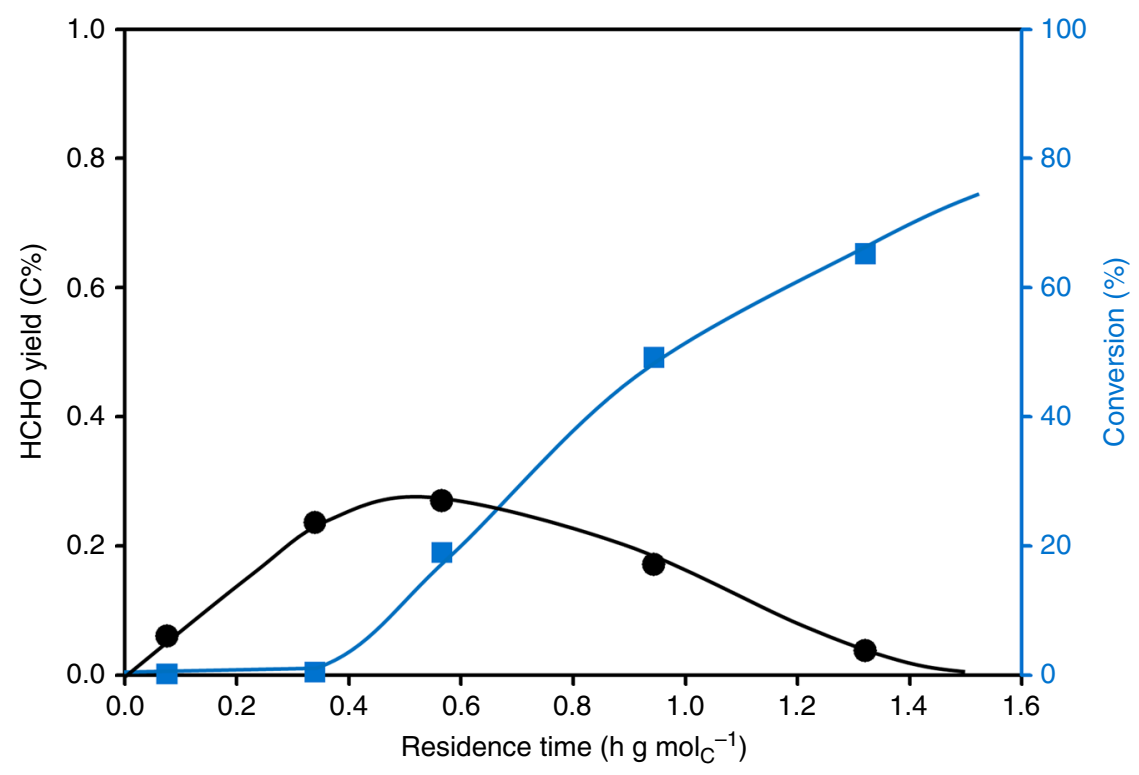

Fig. 1 Methanol conversion and the yield of $\mathrm{HCHO}$ as a function of residence time. Reaction conditions: DME 90 mbar, $\mathrm{H}-\mathrm{ZSM} 5$ (Si/Al 90 steamed) $475{ }^{\circ} \mathrm{C}$
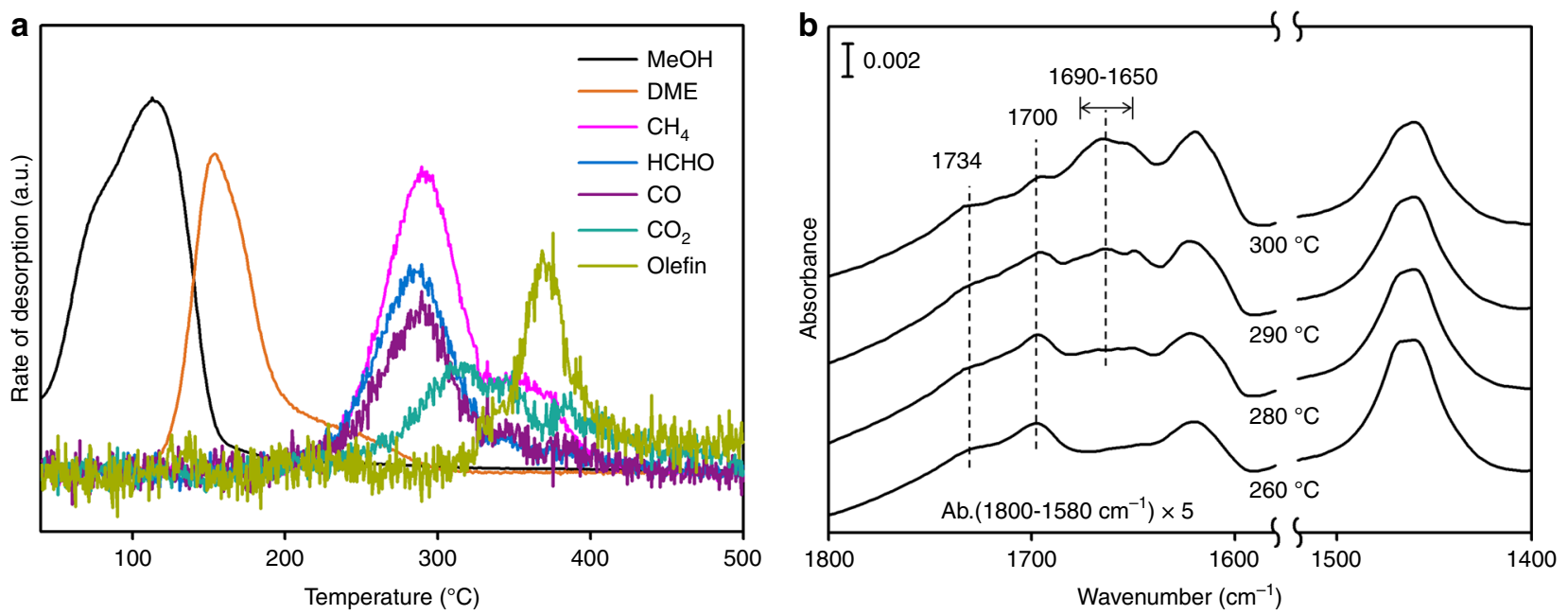

Fig. 2 Surface reaction of $\mathrm{MeOH}$ adsorbed on $\mathrm{H}-\mathrm{ZSM}-5$ with increasing temperature. a Desorbed products in gas phase; $\mathbf{b}$ IR spectrum of corresponding surface species on $\mathrm{H}-\mathrm{ZSM}-5$ taken in situ. Reaction conditions: $\mathrm{H}-\mathrm{ZSM}-5$ (Si/Al 15) $25 \mathrm{mg}$ saturated under 3 mbar MeOH subsequently outgassed under vacuum, afterwards ramping temperature with $3^{\circ} \mathrm{C} \mathrm{min}^{-1}$ under vacuum

different pathway than that $\mathrm{Wu}$ et al. proposed. Noticeably, $\mathrm{CO}_{2}$ was also observed after $\mathrm{MeOH}$ decomposition and before the onset of olefin desorption. The formation of $\mathrm{CO}_{2}$ prior to the formation of alkenes in the early stages of the MTH reaction has been attributed to ketonic decarboxylation of two acetic acid molecules into acetone and $\mathrm{CO}_{2}{ }^{18}$. The present results suggest, however, that this pathway is minor, because acetone was not detected under the present reaction conditions.

IR spectra recorded during this process show the formation and evolution of carbonyl-containing species during the $\mathrm{MeOH}$ surface reactions (Fig. 2b). At $260^{\circ} \mathrm{C}$, four bands were observed between 1800 and $1400 \mathrm{~cm}^{-1}$ : (i) bands of the deformation vibration of water at $1630 \mathrm{~cm}^{-1}$, (ii) bands of $\mathrm{C}-\mathrm{H}$ deformation vibrations at $1460-1470 \mathrm{~cm}^{-1}\left(\mathrm{O}-\mathrm{CH}_{3}\right)^{30}$, and (iii) two bands of $\mathrm{C}=\mathrm{O}$ stretching vibrations at $1700 \mathrm{~cm}^{-1}$ attributed to acetate $\left(\mathrm{O}-\mathrm{CO}-\mathrm{CH}_{3}\right)^{31,32}$ and at $1734 \mathrm{~cm}^{-1}$ to formate $(\mathrm{O}-\mathrm{CO}-\mathrm{H})$ groups $^{33}$, respectively. At this temperature, gas phase analysis showed that DME, $\mathrm{HCHO}, \mathrm{CO}$ and $\mathrm{CH}_{4}$ evolved. We hypothesize, therefore, that these $\mathrm{C}_{1}$ species are involved in the formation of the surface species observed in the IR spectra.

The methoxy group is formed by dissociative adsorption of $\mathrm{MeOH} / \mathrm{DME}$ on Brønsted acid sites. Acetate groups are formed by $\mathrm{CO}$ insertion into the $\mathrm{O}-\mathrm{CH}_{3}$ bond of methoxy groups ${ }^{32,34-38}$ while formate groups are attributed to be the products of the disproportionation of $\mathrm{HCHO}$ under hydrothermal conditions ${ }^{39}$. With reaction progress (here observed when temperature increased from 280 to $300^{\circ} \mathrm{C}$ ), the acetate $\mathrm{C}=\mathrm{O}$ stretching vibrations at 1700 $\mathrm{cm}^{-1}$ shifts to $1690-1650 \mathrm{~cm}^{-1}$. This red shift is attributed to the transformation of acetate groups into unsaturated carboxylates, i.e., acrylate, making conjugated carbonyl groups. This reaction went through the condensation of $\mathrm{HCHO}$ at the acetate methyl group (Fig. 3) ${ }^{40}$. The unsaturated carboxylates have also been proposed to convert, via stepwise condensations with $\mathrm{HCHO}$, to O-containing species, strongly interacting with $\mathrm{BAS}^{21}$. Note that formation of this unsaturated carboxylates occurred in parallel with the $\mathrm{CO}_{2}$ evolution at $280^{\circ} \mathrm{C}$, indicating that partial decarboxylation took place. The evolution of alkenes was then observed at $300^{\circ} \mathrm{C}$ (Fig. 2a). This 


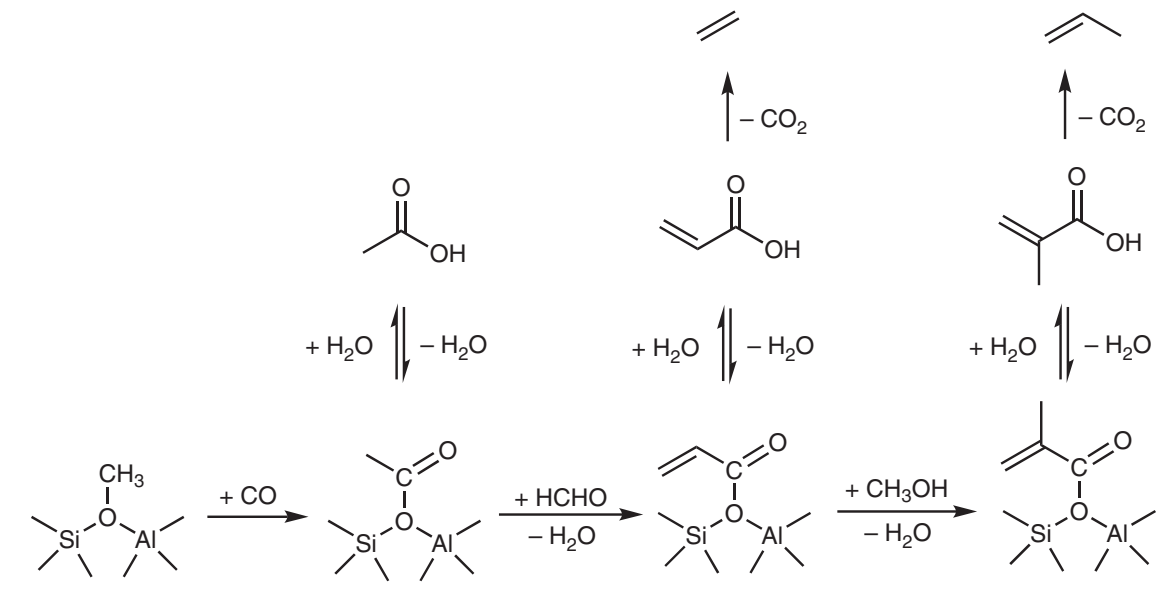

Fig. 3 Schematic illustration of the proposed reaction pathways for the formation of alkenes. Surface methoxy group undergoes carbonylation into acetyl group and desorbs as acetic acid, which stepwise converts to unsaturated carboxylic acid, e.g. acrylic acid and methacrylic acid. Ethene and propene are formed via decarboxylation of the unsaturated carboxylic acids

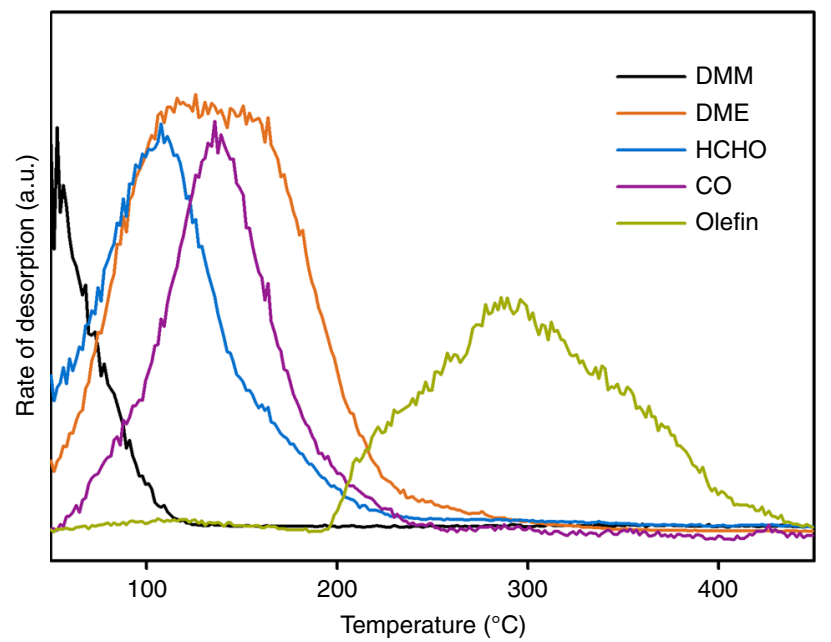

Fig. 4 Surface reaction of DMM adsorbed on $\mathrm{H}-\mathrm{ZSM}-5$ with increasing temperature. Reaction conditions: H-ZSM-5 (Si/Al 15) 25 mg saturated under 1 mbar DMM, subsequently outgassed under vacuum, afterwards ramping temperature with $3^{\circ} \mathrm{C} \mathrm{min}^{-1}$ under vacuum

strongly suggests that decarboxylation of unsaturated carboxylic acids plays a role in the formation of the first olefinic products (Fig. 3). An alternative pathway, the methylation of acetate-derived ketene to propionate followed by decarbonylation ${ }^{36-38}$, may also occur in parallel, but is less important under the applied condition here, because neither ketene nor propionate were observed.

A similar temperature-programmed surface reaction was performed with dimethoxymethane (DMM) instead of $\mathrm{MeOH}$ (Fig. 4). On H-ZSM-5, DMM decomposes into equimolar concentration of $\mathrm{HCHO}$ and DME below $100^{\circ} \mathrm{C}$. Thus, the surface reaction of DMM at $\mathrm{T}>100^{\circ} \mathrm{C}$ represents the reaction of a mixture of $\mathrm{HCHO}$ and DME on H-ZSM-5. The evolution of alkenes started in this case at $\sim 200^{\circ} \mathrm{C}$, while in pure $\mathrm{MeOH}$ alkenes did not appear until $300^{\circ} \mathrm{C}$ (Fig. 2a). Converting $\mathrm{MeOH}$ required temperatures above $200^{\circ} \mathrm{C}$ to generate $\mathrm{HCHO}$ and $\mathrm{CO}$. In presence of $\mathrm{HCHO}$ and $\mathrm{CO}$ the reaction started already below $200{ }^{\circ} \mathrm{C}$, facilitating the initiation of the hydrocarbon pool at low temperatures.

Participation of formaldehyde in the dual-cycle mechanism. Having shown how HCHO participates in the formation of

\begin{tabular}{|c|c|c|}
\hline Feed composition & MeOH & $\begin{array}{l}\mathrm{MeOH}+5 \mathrm{C} \% \\
\mathrm{H}^{13} \mathrm{CHO}\end{array}$ \\
\hline $\begin{array}{l}\text { Conversion (C\%) } \\
\text { Product selectivity (C\%) }\end{array}$ & 88.8 & 75.8 \\
\hline Ethene & 3.0 & 8.6 \\
\hline Propene & 36.9 & 28.1 \\
\hline Butene & 20.3 & 15.8 \\
\hline Dienes $^{b}$ & 0.4 & 0.7 \\
\hline Aromatics & 2.4 & 12.2 \\
\hline $\mathrm{C}_{1-4}$ alkanes & 3.1 & 2.8 \\
\hline $\mathrm{C}_{5+}$ aliphatics & 20.2 & 20.1 \\
\hline
\end{tabular}

the first olefin, we investigate next its participation in the dualcycle mechanism. Because $\mathrm{HCHO}$ is $\mathrm{H}$-poor, incorporation into products must increase the selectivity to aromatic molecules ${ }^{20,24}$, and in turn the selectivity to ethene, formed in the aromatic cycle $^{20}$. As the formation of aromatic molecules has been associated to deactivation of the zeolite catalysts, we hypothesize that the higher concentration of $\mathrm{HCHO}$ in the reacting mixture leads to faster deactivation of the catalyst ${ }^{20}$.

In order to show the most relevant conversion pathways of $\mathrm{HCHO},{ }^{13} \mathrm{C}$-labeled $\mathrm{HCHO}$ was co-fed with $\mathrm{MeOH}$. Table 2 shows the selectivity to hydrocarbon products when feeding pure $\mathrm{MeOH}$ and $\mathrm{MeOH}$ with $5 \mathrm{C} \% \mathrm{HCHO}$ at comparable conversion levels ( $88.8 \mathrm{C} \%$ and $75.8 \mathrm{C} \%$, respectively). For pure $\mathrm{MeOH}$ feed, propene and butene were the major products, with selectivities of $36.9 \mathrm{C} \%$ and $20.3 \mathrm{C} \%$, respectively. Ethene selectivity was only $3.0 \mathrm{C} \%$, in good agreement with the low yield of aromatics $(2.4 \mathrm{C} \%)$. The products indicate that under the selected reaction conditions the aromatic cycle was less important than the olefin cycle. The selectivity to $\mathrm{C}_{1-4}$ alkanes was at the same low level as aromatics, indicating low rate of hydrogen transfer reactions.

When $\mathrm{HCHO}$ was co-fed with $\mathrm{MeOH}$, the selectivity to $\mathrm{H}$-poor products, i.e., dienes and aromatics, increased drastically. The selectivity to aromatic molecules increased five-fold from 2.4 to $12.2 \mathrm{C} \%$. The ethene selectivity increased from 3.0 to $8.6 \mathrm{C} \%$. In parallel, the selectivities to propene and butene decreased from $36.9 \mathrm{C} \%$ to 28.1 and from 20.3 to $15.8 \mathrm{C} \%$, respectively. These 

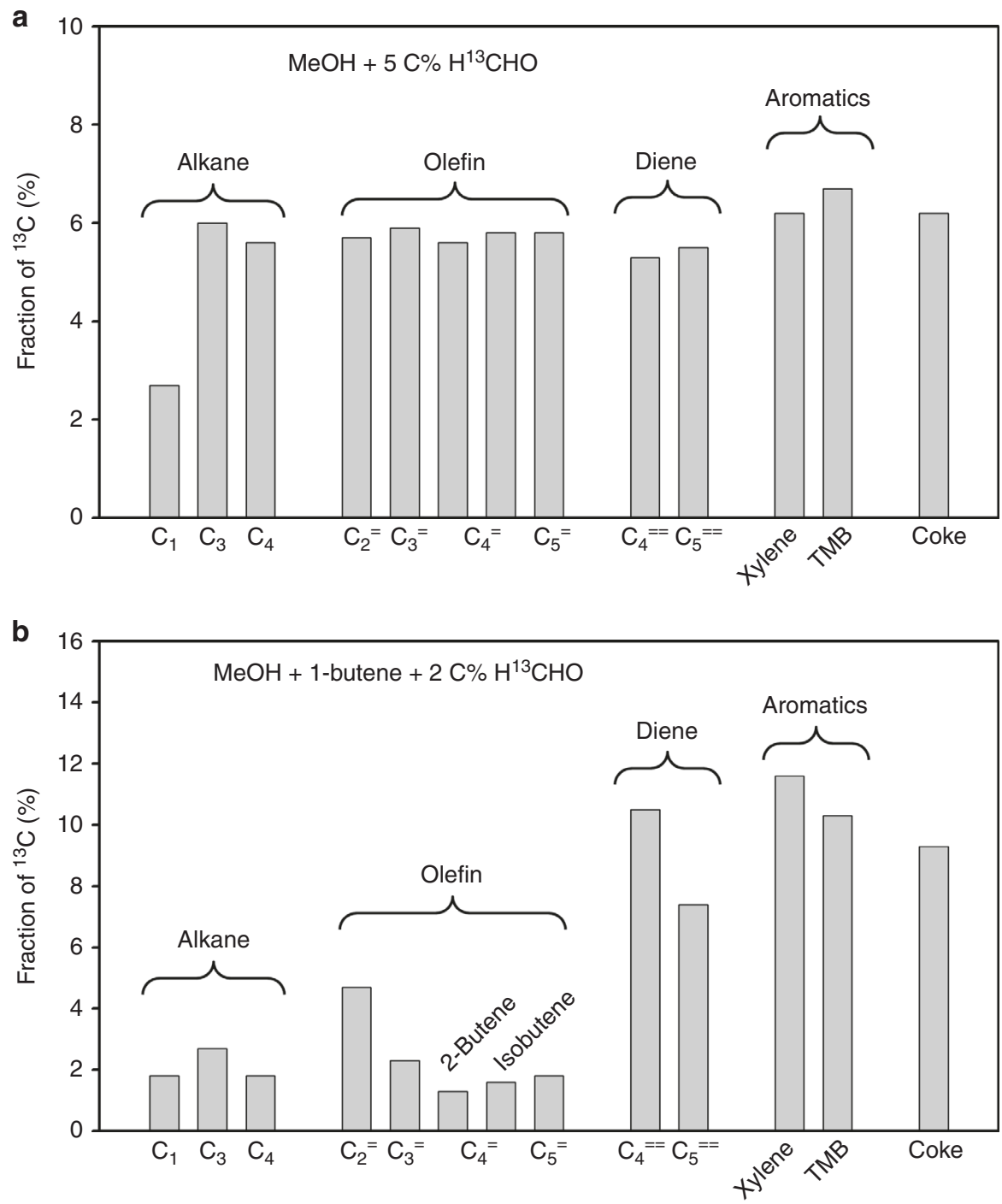

Fig. 5 Fraction of ${ }^{13} \mathrm{C}$ in hydrocarbon products in the reaction of $\mathrm{MeOH}$ cofed with $\mathrm{H}^{13} \mathrm{CHO}$. a $\mathrm{MeOH}$ cofed with $5 \mathrm{C} \% \mathrm{H}^{13} \mathrm{CHO}, \mathrm{MeOH}$ conversion $75 \%$. b $\mathrm{MeOH}$ cofed with 1-butene and $2 \mathrm{C} \% \mathrm{H}^{13} \mathrm{CHO} ; \mathrm{MeOH}$ conversion $100 \%$, butene decreased from $57 \%$ in the feedstock to $24 \%$ in the gas products. $\mathrm{C}_{2}=, \mathrm{C}_{3}=, \mathrm{C}_{4}=$ and $\mathrm{C}_{5}=$ refer to ethene, propene, butene and pentene, respectively; $\mathrm{C}_{4}==$ and $\mathrm{C}_{5}==$ refer to butadiene and pentadiene respectively. Reaction conditions: a W/F $1.82 \mathrm{~h} \cdot \mathrm{g}_{(\mathrm{cat})} \cdot \mathrm{mol}_{(\mathrm{MeOH}+\mathrm{HCHO})}{ }^{-1}, \mathrm{MeOH} 171 \mathrm{mbar}, \mathrm{H}^{13} \mathrm{CHO} 9 \mathrm{mbar}, \mathrm{H}_{2} \mathrm{O} 60 \mathrm{mbar}, 475^{\circ} \mathrm{C} ; \mathbf{b}^{\mathrm{W}} \mathrm{W} / \mathrm{F} 1.30 \mathrm{~h} \cdot \mathrm{g}_{(\mathrm{cat})} \cdot \mathrm{mol}_{(\mathrm{MeOH}+\mathrm{HCHO})}{ }^{-1}, \mathrm{MeOH}$ $171 \mathrm{mbar}, \mathrm{H}^{13} \mathrm{CHO} 9 \mathrm{mbar}, \mathrm{H}_{2} \mathrm{O} 60 \mathrm{mbar}$, 1-butene $60 \mathrm{mbar}, 475^{\circ} \mathrm{C}$. See Supplementary Methods 1 and 2 for the determination of ${ }^{13} \mathrm{C}$ fraction

changes indicate that in presence of $\mathrm{HCHO}$ the olefin cycle decreased in importance. The selectivity to $\mathrm{C}_{1-4}$ alkanes did not change, which indicates that the hydrogen transfer rate was not affected by the presence of $\mathrm{HCHO}$. Thus, the increase of dienes and aromatics is concluded to be the result of a direct reaction between alkenes and HCHO.

The distribution of ${ }^{13} \mathrm{C}$ in the products can be used to deduce the reaction pathways in which $\mathrm{HCHO}$ is preferentially incorporated into hydrocarbons. Figure 5 a shows the fraction of each hydrocarbon product containing ${ }^{13} \mathrm{C}$. All hydrocarbon products had a similar percentage of ${ }^{13} \mathrm{C}$ incorporated, within 5 to $6 \%$, corresponding to the total ${ }^{13} \mathrm{C}$ content of the feed. Only methane showed a significantly lower fraction of $2.7 \%$. This uniform distribution of ${ }^{13} \mathrm{C}$ in the product mixture and particularly the value close to ${ }^{13} \mathrm{C}$ fraction in the feed (accounting for the natural abundance of $1 \%{ }^{13} \mathrm{C}$ in $\mathrm{MeOH}$ ) indicates a fast scrambling of ${ }^{13} \mathrm{C}$ during reaction.

The scrambling is hypothesized to result from the fast interconversion of $\mathrm{MeOH}$ with $\mathrm{H}^{13} \mathrm{CHO}$ via hydride transfer from $\mathrm{MeOH}$ to a protonated $\mathrm{H}^{13} \mathrm{CHO}$ on a BAS, which generates a ${ }^{13} \mathrm{C}-$ labeled $\mathrm{MeOH}\left({ }^{13} \mathrm{CH}_{3} \mathrm{OH}\right)$ and an unlabeled $\mathrm{HCHO}(\mathrm{Rxn} 4)$.

$$
\mathrm{CH}_{3} \mathrm{OH}+\mathrm{H}^{13} \mathrm{CHO} \rightarrow \mathrm{HCHO}+{ }^{13} \mathrm{CH}_{3} \mathrm{OH}
$$

This hypothesis is supported by the detection of $5.5 \%$ of ${ }^{13} \mathrm{C}$ labelled $\mathrm{MeOH}$ and concurrently $\mathrm{HCHO}$ with only $8.7 \%{ }^{13} \mathrm{C}$ at $\mathrm{MeOH}$ conversions as low as $5 \mathrm{C} \%$. The low ${ }^{13} \mathrm{C}$ fraction in methane indicates that it is formed mainly in reactions during the initiation stage of the methanol conversion to hydrocarbons (Rxn 1), occurring before and in parallel to the $\mathrm{MeOH} / \mathrm{HCHO}$ scrambling in Rxn 4. Thus, the fast scrambling of $\mathrm{MeOH}$ with $\mathrm{H}^{13} \mathrm{CHO}$ before the appearance of alkenes does not allow tracking the conversion pathway of $\mathrm{H}^{13} \mathrm{CHO}$.

It has been reported that co-feeding alkenes, such as propene and butene quickly initiates the olefin cycle and subsequently also the aromatic cycle ${ }^{4}$. Although under such conditions the hydrogen transfer from $\mathrm{MeOH}$ to $\mathrm{H}^{13} \mathrm{CHO}$ still exist, the extent of scrambling is hypothesized to be significantly reduced, because of the accelerated rate of $\mathrm{MeOH}$ (or $\mathrm{HCHO}$ ) consumption in forming $\mathrm{C}-\mathrm{C}$ bonds by alkylation. Therefore, 1-butene was co-fed with $\mathrm{MeOH}$ and $\mathrm{H}^{13} \mathrm{CHO}$ (Fig. 5b). A higher incorporation of ${ }^{13} \mathrm{C}$ was 
observed in dienes and aromatics: $10.5 \%$ in butadiene, $7.4 \%$ in pentadiene, $11.6 \%$ in xylene and $10.3 \%$ in trimethylbenzene (TMB). In contrast, alkanes had only about $2 \%$ of ${ }^{13} \mathrm{C}$. Within alkenes, ethene had the highest ${ }^{13} \mathrm{C}$ fraction (4.7\%); for propene it was $2.3 \%$ and for butene and pentene even lower (1.3\% for 2-butene, $1.6 \%$ for isobutene and $1.8 \%$ for pentene). The total ${ }^{13} \mathrm{C}$ content in the gas products was $2.9 \%$, very close to the $3.1 \%{ }^{13} \mathrm{C}$ in the feedstock $(2 \%$ from $\mathrm{H}^{13} \mathrm{CHO}$ and $1.1 \%$ from natural abundance in $\mathrm{MeOH}$ and butene), in which the $0.2 \%$ difference could be those incorporated in ${ }^{13} \mathrm{CO},{ }^{13} \mathrm{CO}_{2}$ or coke. These results show that $\mathrm{HCHO}$ participates in both cycles as a $\mathrm{C}_{1}$ source. Ethene is formed in the aromatic cycle and the high incorporation of ${ }^{13} \mathrm{C}$ in ethene and aromatic molecules indicates a high involvement of $\mathrm{H}^{13} \mathrm{CHO}$ in the aromatic cycle. Both pentene and isobutene are products and intermediates in olefin cycle. Although the direct skeletal isomerization of the cofed 1butene to isobutene is possible, this pathway has only a minor contribution on H-ZSM-5 and most isobutene is generated from cracking of higher olefins ${ }^{41,42}$. Therefore, their low incorporation of ${ }^{13} \mathrm{C}$ indicates a minor participation of $\mathrm{H}^{13} \mathrm{CHO}$ in the olefin cycle.

Isobutene is chosen as indicator of the olefin cycle, because the other two butene isomers are either the co-fed reactant (1-butene) or can be formed by 1-butene isomerization on BAS without passing the olefin cycle (2-butene). Propene is generated in both the aromatic and the olefin cycle $e^{1,2,4}$, showing in consequence a ${ }^{13} \mathrm{C}$ incorporation level intermediate between ethene and isobutene. The preferred ${ }^{13} \mathrm{C}$ enrichment of dienes and aromatics supports earlier conclusions that $\mathrm{HCHO}$ leads to $\mathrm{H}$-poor products at a rate that is higher than that of hydrogen transfer between hydrogen poor and hydrogen rich hydrocarbon intermediates.

$$
\begin{aligned}
& \mathrm{C}_{4} \mathrm{H}_{8}+\mathrm{C}_{4} \mathrm{H}_{8} \rightarrow \mathrm{C}_{4} \mathrm{H}_{6}+\mathrm{C}_{4} \mathrm{H}_{10} \\
& \mathrm{C}_{4} \mathrm{H}_{8}+\mathrm{HCHO} \rightarrow \mathrm{C}_{5} \mathrm{H}_{8}+\mathrm{H}_{2} \mathrm{O}
\end{aligned}
$$

An alkene, for e.g., butene, can react into a diene in MTO via two pathways, hydrogen transfer with another alkene (Rxn 5) and Prins reaction with a formaldehyde (Rxn 6). Unlike hydrogen transfer, the Prins reaction has not attracted much attention until recently. Earlier reports have, however, noted the possibility of Prins type reaction for the formation of dienes and aromatics without experimental evidence ${ }^{20,24}$. Comparing the isotope distribution allows now unequivocally establishing the importance of the two routes. If hydrogen transfer were the dominant path of diene formation ( $R x n 5$ ), butadiene and pentadiene would have a ${ }^{13} \mathrm{C}$ labelling similar to that of butene and pentene, respectively. The fact that eight times more ${ }^{13} \mathrm{C}$ was found in butadiene $(10.5 \%)$ than in $n$-butene $(1.3 \%)$ and over four times more ${ }^{13} \mathrm{C}$ in pentadiene $(7.4 \%)$ than in pentene $(1.8 \%)$ when $\mathrm{MeOH}$ was reacted together with 1-butene and $2 \mathrm{C} \% \mathrm{H}^{13} \mathrm{CHO}$, allowed us to rule out hydrogen transfer as the main pathway to dienes. Moreover, the rate of hydrogen transfer has been reported to increase by one order of magnitude by the simultaneous presence of $\mathrm{MeOH}$ and alkenes, attributed to the reaction pathway involving hydrogen transfer from $\mathrm{MeOH}$ to an alkene ${ }^{24}$. Such reaction generates formaldehyde in situ, which, as discussed above, reacts subsequently by Prins reaction converting a second alkene to a diene ( $\mathrm{Rxn} 7$ ). Therefore, we conclude that the Prins reaction is the dominant pathway for diene formation.

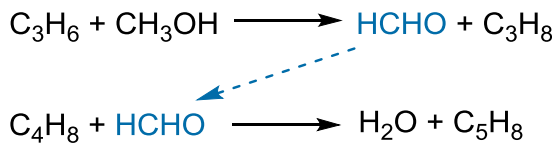

This conclusion is further supported by an additional experiment in which 1-butene was reacted with $\mathrm{H}^{13} \mathrm{CHO}$ in absence of $\mathrm{MeOH}$. The resulting pentadiene from this reaction had a labelling of $\sim 20 \%{ }^{13} \mathrm{C}$ (Supplementary Fig. 1), indicating an incorporation of one ${ }^{13} \mathrm{C}$ in each pentadiene molecule via a Prins type reaction ( $\mathrm{Rxn} 8$ ). In the reaction of $\mathrm{MeOH}$ with butene and $\mathrm{H}^{13} \mathrm{CHO}$, the incorporation of ${ }^{13} \mathrm{C}$ in pentadiene was much lower $\left(7.4 \%{ }^{13} \mathrm{C}\right.$, Fig. $\left.5 \mathrm{~b}\right)$. We speculate that this is caused by $\mathrm{H}^{13} \mathrm{CHO}$ being partially interconverted with unlabeled $\mathrm{HCHO}$ generated in situ from $\mathrm{MeOH}$ via Rxn 4 and Rxn 7.

$$
\mathrm{C}_{4} \mathrm{H}_{8}+\mathrm{H}^{13} \mathrm{CHO} \rightarrow{ }^{13} \mathrm{C}_{1} \mathrm{C}_{4} \mathrm{H}_{8}+\mathrm{H}_{2} \mathrm{O}
$$

After showing the participation of $\mathrm{HCHO}$ in the dual cycle via Prins reaction, we discuss the importance of this reaction pathway in typical MTO reaction for the non-olefinic byproduct formation. In order to do so, we compare the reaction rates of Prins reaction and hydrogen transfer between alkenes in H-ZSM-5. To avoid the interference of products directly formed via $\mathrm{MeOH}$ routes, we examine these reactions by studying the reaction of 1-butene -chosen as representative of the olefin pool - with $\mathrm{HCHO}$ on $\mathrm{H}$ ZSM-5. Figure 6a shows the product yield in the reaction of 45 mbar 1-butene with 0.32 mbar HCHO. The $\mathrm{HCHO}$ concentration was chosen as $0.18 \mathrm{C} \%$ in the total feed, corresponding to the average concentration derived from the yield of $\mathrm{HCHO}$ during MTO reaction at different contact times (as shown in Fig. 1). Butene dimerization and cracking were the dominant reactions leading to a $0.72 \mathrm{C} \%$ yield of propene, $1.2 \mathrm{C} \%$ yield of pentene and $0.17 \mathrm{C} \%$ yield of higher aliphatic products at $0.17 \mathrm{~h} \mathrm{~g}_{\mathrm{cat}} \mathrm{mol}_{\mathrm{C}}{ }^{-1}$ residence time (Fig. 6a). In addition, small concentrations of pentadiene, butadiene and butane were formed (Fig. 6a). Pentadiene is the product from Prins reaction of butene with HCHO (Rxn 6) while butane is formed via hydrogen transfer reaction ( $\mathrm{Rxn} 5$ ). Butadiene can be formed both from Prins reaction of propene with $\mathrm{HCHO}$ and from hydrogen transfer reaction.

Therefore, the rates of pentadiene and butane formation represent the rates of Prins reaction and hydrogen transfer, respectively. As it can be seen in Fig. 6b, the rate of Prins reaction is one order of magnitude higher than that of hydrogen transfer, even though the concentration of $\mathrm{HCHO}$ was two orders of magnitude lower than that of butene. These results provide unequivocal evidence for previous speculations that the Prins reaction is the major route of $\mathrm{HCHO}$ being converted to $\mathrm{H}$-poor products in the MTO process, i.e., dienes and aromatics ${ }^{18,20}$. As a reference, the rate of methylation, which represents the rate of the dual cycles, derived from a standard MTO feed (Fig. 1) is also included in Fig. 6b. It can be concluded that the reactions in the dual cycle are dominant in MTO, because the methylation rate is two orders of magnitude higher than the rate of Prins reaction. However, formaldehyde forms aromatics and $\mathrm{H}$-poor products selectively, even if present only in low concentrations. Thus, it impacts the product distribution of the overall MTO process. The presence of $\mathrm{HCHO}$ acts in analogy to the established effect of co-feeding small concentrations of aromatics with $\mathrm{MeOH}$ on $\mathrm{H}-\mathrm{ZSM}-5^{4}$, which leads to enhancement of the aromatic cycle, shifting the selectivity of the process towards aromatics and ethene.

Role of formaldehyde in deactivation. Aromatic molecules are coke precursors in $\mathrm{MTO}^{21,22,25}$. The higher yield of aromatics induced by the presence of $\mathrm{HCHO}$ will, thus, cause a higher coking and deactivation rates. This is supported by the sharp decline of conversion with time on stream for the reactions of $\mathrm{MeOH}$ with $5 \mathrm{C} \%$ cofed $\mathrm{H}^{13} \mathrm{CHO}$ in contrast to pure $\mathrm{MeOH}$ feeds (Fig. 7). It is shown in Section 2.1 that the presence of $\mathrm{HCHO}$ would promote reactivity by facilitating the first olefin formation. However, because of the strong deactivation induced when $5 \mathrm{C} \%$ of $\mathrm{MeOH}$ is replaced by $\mathrm{H}^{13} \mathrm{CHO}$, under the same reaction conditions, the conversion dropped below $80 \%$ after only 10 min time on stream and to approximately $5 \%$ after 100 min. Conversely, when butene was co-fed with $\mathrm{MeOH}$ and $\mathrm{HCHO}$, the 

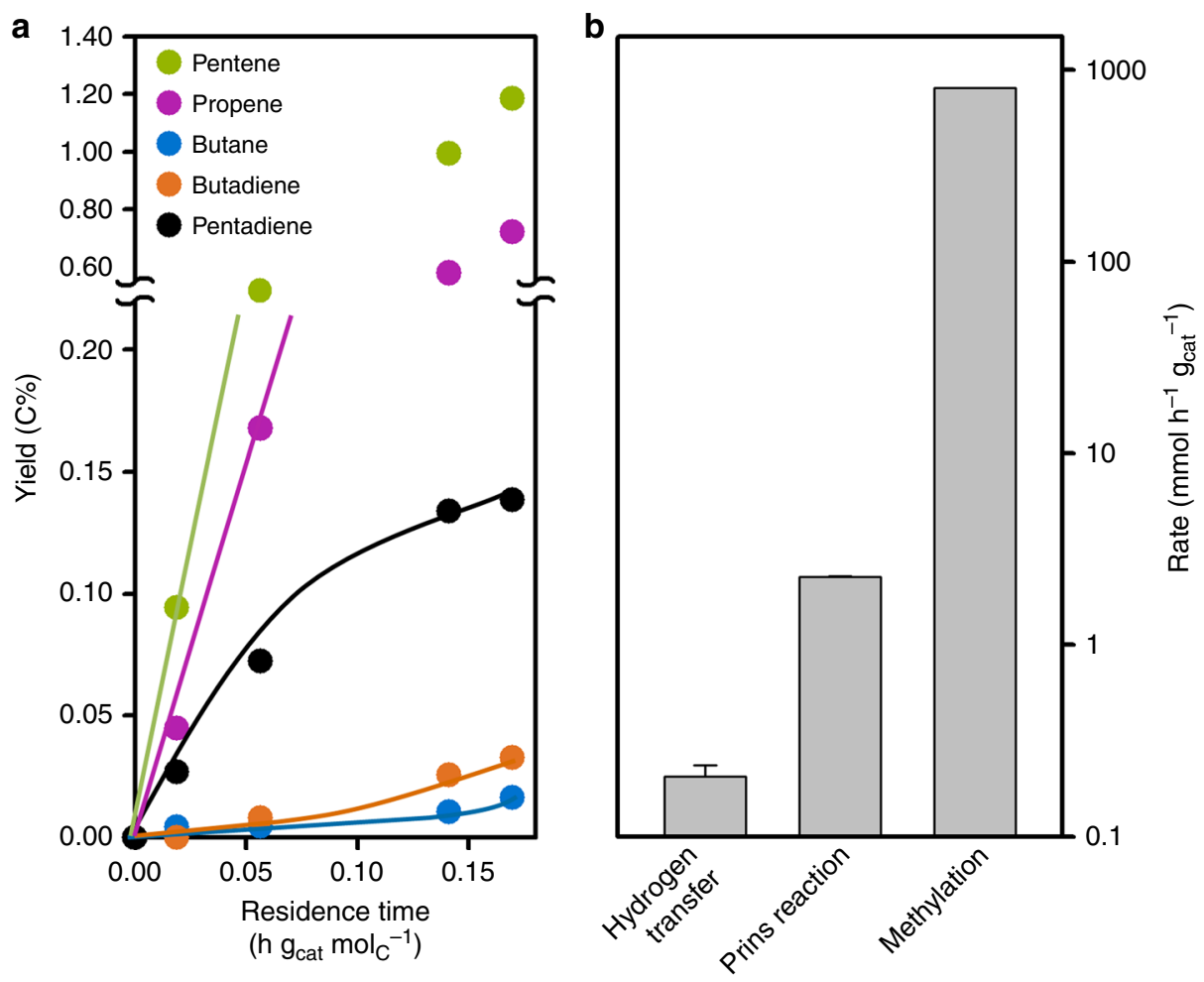

Fig. 6 Reaction of 1-butene with $\mathrm{HCHO}$ over H-ZSM-5. a Product yield as a function of residence time. Reaction condition: 1-butene 45 mbar, $\mathrm{HCHO} 0.32$ mbar, $\mathrm{H}_{2} \mathrm{O} 22.5 \mathrm{mbar}, 475^{\circ} \mathrm{C}$. b Reaction rates obtained for hydrogen transfer, Prins reaction (initial rates of formation of butane and pentadiene respectively under reaction conditions shown in a and methylation (represented by the $\mathrm{DME} / \mathrm{MeOH}$ conversion rate at $\sim 40 \%$ conversion shown in Fig. 1) on $\mathrm{H}-\mathrm{ZSM}-5$. Error bar represents the standard error of the reactions rates

fast consumption of $\mathrm{MeOH}$ and $\mathrm{HCHO}$ via alkylation and Prins reaction with butene lead to their full conversion at the contact time studied. The conversion only dropped slightly to $98.5 \%$ after 100 min time on stream (Supplementary Fig. 2). This agrees well with previous conclusions that the presence of alkenes drastically prolongs catalyst lifetime ${ }^{10,21}$.

The carbon deposits on H-ZSM-5 using different feeds were analyzed after $100 \mathrm{~min}$ time on stream and results are compiled in Table 3. The reaction of pure $\mathrm{MeOH}$ feed for $100 \mathrm{~min}$ accumulated $1.0 \mathrm{wt} \%$ of coke on catalyst. In contrast, co-feeding $5 \mathrm{C} \% \mathrm{H}^{13} \mathrm{CHO}$ increased the deposited coke to 5.2 wt.\%. Normalizing the coke concentration to the converted $\mathrm{MeOH}$ showed that only $0.084 \mathrm{C} \%$ of pure $\mathrm{MeOH}$ feed are converted to coke, but $1.3 \mathrm{C} \%$ for $\mathrm{MeOH}$ co-fed with $5 \mathrm{C} \% \mathrm{H}^{13} \mathrm{CHO}$. We conclude that the high rate of coke formation in presence of $\mathrm{HCHO}$ is attributed to the observed higher yield towards $\mathrm{H}$-poor products.

When butene was co-fed to $\mathrm{MeOH}$ and $\mathrm{HCHO}, 7.7$ wt.\% coke was deposited, corresponding to $0.37 \mathrm{C} \%$ of the total converted $\mathrm{MeOH}$. This lower coke formation per converted $\mathrm{MeOH}$ in the presence of butene, is attributed to the successful competition of methylation of butene, decreasing the local concentration of $\mathrm{MeOH}$ along the catalyst bed and, as a consequence, the concentration of $\mathrm{HCHO}$ (formed by $\mathrm{MeOH}$ hydrogen transfer).

The ${ }^{13} \mathrm{C}$ content of coke was analyzed by measuring the fraction of ${ }^{13} \mathrm{CO}$ and ${ }^{13} \mathrm{CO}_{2}$ in total $\mathrm{CO}$ and $\mathrm{CO}_{2}$ during its combustion in temperature-programmed oxidation. The fast scrambling of ${ }^{13} \mathrm{C}$ in $\mathrm{H}^{13} \mathrm{CHO}$ with $\mathrm{MeOH}(\mathrm{Rxn} 4)$ under MTO conditions causes an almost equal distribution of ${ }^{13} \mathrm{C}(5-6 \%)$ in all products, including coke $\left(6.2 \%{ }^{13} \mathrm{C}\right)$ in the reaction of $\mathrm{MeOH}$ with $5 \mathrm{C} \% \mathrm{H}^{13} \mathrm{CHO}$. When the ${ }^{13} \mathrm{C}$ content of coke was analyzed after co-feeding butene with $\mathrm{MeOH}$ and $2 \mathrm{C} \% \mathrm{H}^{13} \mathrm{CHO}$, coke contained $10 \%{ }^{13} \mathrm{C}$, which is comparable to the ${ }^{13} \mathrm{C}$ percentage found in aromatics $\left(11.6 \%{ }^{13} \mathrm{C}\right.$ for xylene and $10.3 \%{ }^{13} \mathrm{C}$ for $\left.\mathrm{TMB}\right)$. This amount

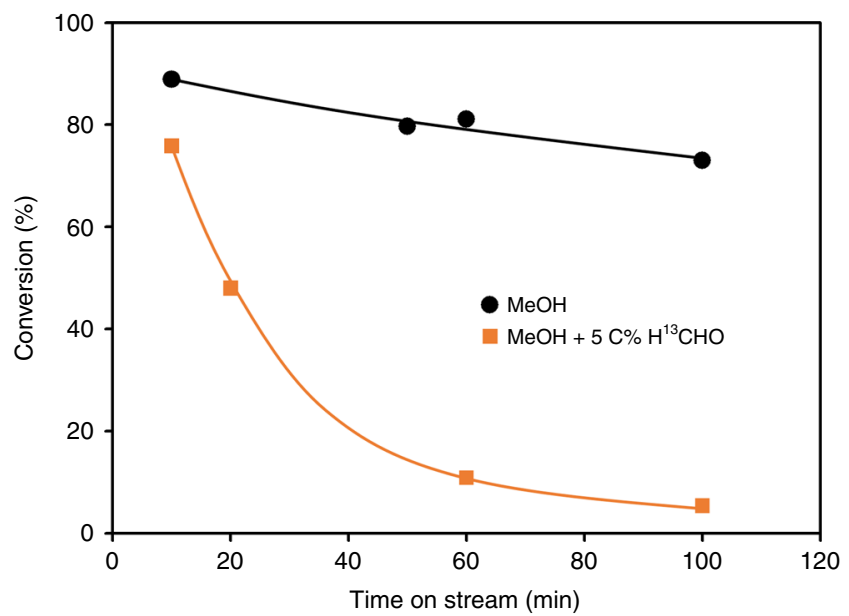

Fig. 7 Evolution of $\mathrm{MeOH}$ conversion during MTO reaction with time on stream. The reactions in presence and absence of cofed $\mathrm{H}^{13} \mathrm{CHO}$ were compared. Reaction conditions: H-ZSM-5 (Si/Al 90 steamed), W/F 1.82 h.g cat $\cdot \mathrm{mol}_{(\mathrm{MeOH}+\mathrm{HCHO})}{ }^{-1}, \mathrm{MeOH} 180$ mbar, $\mathrm{H}_{2} \mathrm{O} 60$ mbar, or $\mathrm{MeOH} 171$ mbar, $\mathrm{H}^{13} \mathrm{CHO} 9$ mbar, $\mathrm{H}_{2} \mathrm{O} 60$ mbar, $475^{\circ} \mathrm{C}$

of ${ }^{13} \mathrm{C}$ in coke corresponds to $0.72 \mathrm{C} \%$ of total converted $\mathrm{H}^{13} \mathrm{CHO}$, which is two-fold higher than the percentage of converted $\mathrm{MeOH}$ that ended up in coke $(0.37 \%)$, showing that $\mathrm{HCHO}$ has a higher fraction incorporated than $\mathrm{MeOH}$.

\section{Discussion}

The present experiments show unequivocally that formaldehyde, methane and $\mathrm{CO}$ are generated from $\mathrm{MeOH}$ under MTO 


\section{Table 3 Coke concentration and extent of ${ }^{13} \mathrm{C}$ labelling after} 100 min time on stream

\begin{tabular}{|c|c|c|c|}
\hline Reactants & $\begin{array}{l}\text { Coke } \\
\text { concentration } \\
\text { on catalyst } \\
\text { (wt.\%) }\end{array}$ & $\begin{array}{l}\text { Coke amount } \\
\text { per total } \\
\text { converted } \\
\text { MeOH }(\mathrm{C} \%)\end{array}$ & $\begin{array}{l}{ }^{13} \mathrm{C} \text { fraction } \\
\text { in coke }(\%)\end{array}$ \\
\hline $\begin{array}{l}\mathrm{MeOH}^{\mathrm{a}} \\
\mathrm{MeOH}+5 \mathrm{C} \% \mathrm{H}^{13} \mathrm{CHO}^{\mathrm{a}} \\
\mathrm{MeOH}+1 \text {-Butene }+2 \mathrm{C}^{13} \mathrm{H}^{13} \mathrm{CHO}^{c}\end{array}$ & $\begin{array}{l}1.0 \\
5.2 \\
7.7\end{array}$ & $\begin{array}{l}0.084 \\
1.3 \\
0.37\end{array}$ & $\begin{array}{r}1.1^{b} \\
6.2 \\
10.0\end{array}$ \\
\hline \multicolumn{4}{|c|}{ 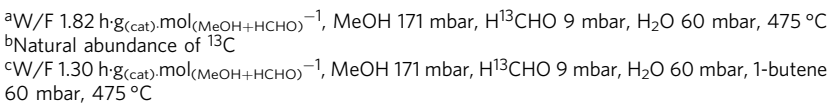 } \\
\hline
\end{tabular}

conditions in H-ZSM-5. We have been able to identify key reaction intermediates in the mechanism of formation of alkenes from a $\mathrm{C}_{1}$ reacting mixture containing $\mathrm{MeOH}, \mathrm{CO}$ and $\mathrm{HCHO}$. $\mathrm{MeOH}$ and DME react with $\mathrm{CO}$ into methyl acetate and acetic acid as the first species containing a C-C bond ${ }^{18,35-38}$. Formaldehyde condenses with surface methyl acetate and acetic acid to form unsaturated carboxylic acids, which then are converted into the first olefin species via decarboxylation. Once the concentration of these olefins in the catalyst surpasses a threshold value, the fast methylation activity of Brønsted acid sites allows for the full development of the MTO dual-cycle reaction network.

Formaldehyde reacts with olefins into dienes via Prins reaction. The Prins reaction is one order of magnitude faster than the hydrogen transfer between two alkenes, which makes it the dominant reaction towards $\mathrm{H}$-poor byproducts, i.e., dienes, aromatics and coke. Even in small concentrations, the presence of HCHO increases the selectivity to aromatics, enhancing the importance of the aromatic cycle in the dual cycle and in turn shifting the process towards a higher selectivity to ethene at expenses of the selectivity to propene and butenes. As an additional consequence, the high yield of aromatics induced by $\mathrm{HCHO}$ leads to a high rate of coke formation and to a high rate of deactivation.

Strategies to extend catalyst lifetime should aim, therefore, to minimize the HCHO concentration during the MTO reactions. This could be conceptually achieved by inhibiting its formation or by its fast decomposition. Indeed, many of the improvements in catalyst lifetime reported in the literature can be attributed to reaction conditions in which the chemical potential of $\mathrm{MeOH}-$ and thus of $\mathrm{HCHO}$ - is reduced in the reactor (via dilution of $\mathrm{MeOH}^{20,26}$, co-feeding alkenes ${ }^{10}$, back-mixing products ${ }^{10,21}$ or replacing $\mathrm{MeOH}$ by $\mathrm{DME}^{19}$ ).

\section{Methods \\ Catalysts. H-ZSM- 5 catalyst with $\mathrm{Si} / \mathrm{Al} 90$ was synthesized according to the procedure described by Ong et al. ${ }^{43}$. In brief, Na-ZSM- 5 was first synthesized by mixing colloidal silica, $\mathrm{Al}\left(\mathrm{NO}_{3}\right)_{3} \cdot 9 \mathrm{H}_{2} \mathrm{O}, \mathrm{NaOH}$ and tetrapropylammonium bro- mide (TPABr) with a composition of $100 \mathrm{SiO}_{2}: 0.2 \mathrm{Al}_{2} \mathrm{O}_{3}: 5 \mathrm{Na}_{2} \mathrm{O}: 10$ TPABr: 4000 $\mathrm{H}_{2} \mathrm{O}$. After aging, the obtained gel was transferred to an autoclave and kept at $180^{\circ} \mathrm{C}$ for $48 \mathrm{~h}$. Then the solid was separated by filtration and washed until $\mathrm{pH} 8$. Afterwards, the powder was dried at $100^{\circ} \mathrm{C}$ overnight and calcined with the fol- lowing sequential steps: (1) rising with $1{ }^{\circ} \mathrm{C} \mathrm{min}-1$ to $200^{\circ} \mathrm{C}$ in flowing $\mathrm{He}$ and kept for $3 \mathrm{~h}$; (2) rising with $1{ }^{\circ} \mathrm{C} \mathrm{min}-1$ to $520^{\circ} \mathrm{C}$ in flowing air and kept for $3 \mathrm{~h}$. The obtained Na-ZSM- 5 was then transformed into H-ZSM- 5 via ion-exchange with $\mathrm{NH}_{4} \mathrm{NO}_{3}$ solution and calcination in flowing air at $520^{\circ} \mathrm{C}$ for $3 \mathrm{~h}$. It has a $\mathrm{Si} / \mathrm{Al}$ ratio of 90 according to atomic absorption spectroscopic analysis. For some experiments, the H-ZSM- 5 was steamed at $753 \mathrm{~K}$ for $24 \mathrm{~h}$ at water vapor pressure of 1 bar prior to usage. Accordingly, the samples are denoted as H-ZSM-5 (Si/Al 90) and H-ZSM-5 (Si/Al 90, steamed). For the TPSR/IR spectroscopy experiment, an H-ZSM-5 with Si/Al 15 was used (named as H-ZSM-5 (Si/Al 15)) which was purchased from Zeolyst. Methanol ( $\geq 99.9 \%)$ and dimethoxymethane $(99 \%)$ were supplied by Sigma-Aldrich. ${ }^{13} \mathrm{C}$-labeled $\mathrm{HCHO}\left(99\right.$ atom $\left.\%{ }^{13} \mathrm{C}\right)$ was purchased from Sigma-Aldrich as aqueous solution (20 wt.\%).}

TPSR and IR spectroscopy. Temperature-programmed surface reactions (TPSR) of $\mathrm{MeOH}$ and DMM were performed in a home-made IR-cell connected to a mass spectrometer. A self-supporting wafer of $25 \mathrm{mg} \mathrm{H}-\mathrm{ZSM}-5$ ( $\mathrm{Si} / \mathrm{Al} \mathrm{15)}$ was loaded in the cell center and perpendicular to the IR beam. The H-ZSM-5 (Si/Al 15) has a high acid site concentration and high adsorption capacity of $\mathrm{MeOH}$ and DMM, and led, thus, to higher intensities of the bands in the IR spectra. The wafer was first activated at $723 \mathrm{~K}$ in vacuum for $1 \mathrm{~h}$. After cooling down to $40^{\circ} \mathrm{C}, 3 \mathrm{mbar}$ $\mathrm{MeOH}$ or $1 \mathrm{mbar} \mathrm{DMM}$ was introduced into the cell and kept for $15 \mathrm{~min}$ followed by desorption for $30 \mathrm{~min}$ under vacuum. Then, the wafer temperature was increased to $500^{\circ} \mathrm{C}$ with a rate of $3{ }^{\circ} \mathrm{C} \mathrm{min}-1$. Desorbed molecules were detected on line using mass spectrometry: $\mathrm{m} / \mathrm{e} 31$ for $\mathrm{MeOH}, \mathrm{m} / \mathrm{e} 75$ for DMM, m/e 45 for DME (after subtracting fragment ion signal of m/e 45 from DMM), m/e 16 for methane, $\mathrm{m} / \mathrm{e} 30$ for $\mathrm{HCHO}$ (after subtracting fragment ion signal of $\mathrm{m} / \mathrm{e} 30$ from $\mathrm{MeOH}$ ), $\mathrm{m} / \mathrm{e} 44$ for $\mathrm{CO}_{2}, \mathrm{~m} / \mathrm{e} 28$ for $\mathrm{CO}$ (after subtracting fragment ion signal of $\mathrm{m} / \mathrm{e} 28$ from $\mathrm{CO}_{2}$ ), $\mathrm{m} / \mathrm{e} 27$ for olefins. In-situ IR spectra of the wafer were collected on a Bruker Vertex 70 FTIR spectrometer.

Temperature-programmed oxidation of coke on spent catalysts. Thermogravimetric analysis (TGA) on a SETARAM Sensys Evo TGA-DSC was utilized to analyze coke deposited on deactivated catalysts. Typically, $10-20 \mathrm{mg}$ of powdered sample was loaded and treated at $200^{\circ} \mathrm{C}$ in $16 \mathrm{~mL} \mathrm{~min}^{-1} \mathrm{He}$ flow until weight stabilization. Afterwards, the temperature was raised to $650^{\circ} \mathrm{C}$ at $5^{\circ} \mathrm{C} \mathrm{min}-1$ in 16 $\mathrm{mL} \mathrm{min}^{-1} 10 \mathrm{v} \% \mathrm{O}_{2}$ in He flow and kept for $1 \mathrm{~h}$. The coke amount was obtained from the loss of weight and the formed $\mathrm{H}_{2} \mathrm{O}, \mathrm{CO}$ and $\mathrm{CO}_{2}$ were detected online with an MS.

Catalytic testing. Catalytic measurements were performed in a fixed bed quartz reactor with an internal diameter of $6 \mathrm{~mm}$ at $475^{\circ} \mathrm{C}$ and ambient pressure. The H-ZSM-5 catalysts $(200-280 \mu \mathrm{m})$ were homogeneously diluted with silicon carbide (ESK-SiC) in the range of $355-500 \mu \mathrm{m}$ to ensure temperature uniformity. Catalysts were activated at $475^{\circ} \mathrm{C}$ for $1 \mathrm{~h}$ under He atmosphere before reaction. Methanol and water were introduced into the reactor by an HPLCpump combine with a direct evaporator. For cofeeding experiments, 1-butene was fed by MFC (Bronkhorst) and ${ }^{13} \mathrm{C}$-formaldehyde solution $(20 \mathrm{wt} \%)$ was introduced into reactor by mixing with $\mathrm{MeOH}$ and the pump-evaporator combination. Via adjusting mixing ratio and liquid flow as well as the butene and He gas flow, the feeding ratio and partial pressures of 1-butene and ${ }^{13} \mathrm{C}$ formaldehyde were varied, and the partial pressure of water was kept constant at 60 mbar. Products were analyzed online on a gas chromatograph (HP 5890) equipped with a HP-PLOTQ capillary column and an FID detector. A mass spectrometer is used to analyze $\mathrm{H}_{2}$. Formaldehyde is detected by solving the reaction effluent in water at $2{ }^{\circ} \mathrm{C}$ with subsequent stoichiometric Hantzsch reaction as described by $\mathrm{Nash}^{44}$ and quantification by a Varian Cary $50 \mathrm{UV}$-Vis Spectrophotometer. The product yield and selectivity were given on a carbon basis and DME was treated as unconverted Methanol. For the quantification of ${ }^{13} \mathrm{C}$ fraction in the products, a certain volume of product stream was collected and analyzed on a GC-MS (Agilent Technologies 7890 B GC, column: Agilent HP-PLOT Q, $30 \mathrm{~m}, 0.32 \mathrm{~mm}, 20.00 \mu \mathrm{m})$. The analysis of ${ }^{13} \mathrm{C}$ incorporation is described in Supporting Information Methods part.

\section{Data availability}

The source data underlying for Figs. 1, 2, 4-7 are provided as a Source Data file. All other data supporting the findings in this study are available from the authors on request.

Received: 11 December 2018 Accepted: 11 March 2019

Published online: 01 April 2019

\section{References}

1. Olsbye, U. et al. Conversion of methanol to hydrocarbons: how zeolite cavity and pore size controls product selectivity. Angew. Chem. Int. Ed. 51, 5810-5831 (2012)

2. Ilias, S. \& Bhan, A. Mechanism of the catalytic conversion of methanol to hydrocarbons. ACS Catal. 3, 18-31 (2013).

3. Yarulina, I., Chowdhury, A. D., Meirer, F., Weckhuysen, B. M. \& Gascon, J. Recent trends and fundamental insights in the methanol-to-hydrocarbons process. Nat. Catal. 1, 398-411 (2018)

4. Sun, X. Y. et al. On the impact of co-feeding aromatics and olefins for the methanol-to-olefins reaction on HZSM-5. J. Catal. 314, 21-31 (2014).

5. Dahl, I. M. \& Kolboe, S. On the reaction-mechanism for propene formation in the mto reaction over Sapo-34. Catal. Lett. 20, 329-336 (1993).

6. Dahl, I. M. \& Kolboe, S. On the reaction-mechanism for hydrocarbon formation from methanol over Sapo-34 .1. Isotopic labeling studies of the coreaction of ethene and methanol. J. Catal. 149, 458-464 (1994).

7. Dahl, I. M. \& Kolboe, S. On the reaction mechanism for hydrocarbon formation from methanol over SAPO-34 .2. Isotopic labeling studies of the coreaction of propene and methanol. J. Catal. 161, 304-309 (1996).

8. Bjorgen, M. et al. Conversion of methanol to hydrocarbons over zeolite $\mathrm{H}-$ ZSM-5: on the origin of the olefinic species. J. Catal. 249, 195-207 (2007). 
9. Svelle, S. et al. Conversion of methanol into hydrocarbons over zeolite $\mathrm{H}$ ZSM-5: ethene formation is mechanistically separated from the formation of higher alkenes. J. Am. Chem. Soc. 128, 14770-14771 (2006).

10. Sun, X. Y. et al. On reaction pathways in the conversion of methanol to hydrocarbons on HZSM-5. J. Catal. 317, 185-197 (2014).

11. Kubelková, L., Nováková, J. \& Jírů, P. Reaction of small amounts of methanol on HZSM-5, HY and modified y zeolites. Stud. Surf. Sci. Catal. 18, 217-224 (1984).

12. Hutchings, G. J., Gottschalk, F. \& Hunter, R. Kinetic-model for methanol conversion to olefins with respect to methane formation at low conversion comment. Ind. Eng. Chem. Res. 26, 635-637 (1987).

13. Hutchings, G. J., Gottschalk, F., Hall, M. V. M. \& Hunter, R. Hydrocarbon formation from methylating agents over the zeolite catalyst zsm-5 - comments on the mechanism of carbon carbon bond and methane formation. J. Chem. Soc. Faraday Trans. 83, 571-583 (1987).

14. Tajima, N., Tsuneda, T., Toyama, F. \& Hirao, K. A new mechanism for the first carbon-carbon bond formation in the MTG process: a theoretical study. J. Am. Chem. Soc. 120, 8222-8229 (1998).

15. Comas-Vives, A., Valla, M., Coperet, C. \& Sautet, P. Cooperativity between Al sites promotes hydrogen transfer and carbon-carbon bond formation upon dimethyl ether activation on alumina. ACS Cent. Sci. 1, 313-319 (2015).

16. Chu, Y., Yi, X., Li, C., Sun, X. \& Zheng, A. Brønsted/Lewis acid sites synergistically promote the initial C-C bond formation in the MTO reaction. Chem. Sci. 9, 6470-6479 (2018).

17. Wang, C. et al. Extra-framework aluminum-assisted first $\mathrm{C}-\mathrm{C}$ bond formation in methanol-to-olefins conversion on zeolite H-ZSM-5. Angew Chem. Int. Ed. Engl. 57, 10197-10201 (2018).

18. Liu, Y. et al. formation mechanism of the first carbon-carbon bond and the first olefin in the methanol conversion into hydrocarbons. Angew. Chem. Int. Ed. 55, 5723-5726 (2016).

19. Martinez-Espin, J. S. et al. New insights into catalyst deactivation and product distribution of zeolites in the methanol-to-hydrocarbons (MTH) reaction with methanol and dimethyl ether feeds. Catal. Sci. Technol. 7, 2700-2716 (2017).

20. Arora, S. S. \& Bhan, A. The critical role of methanol pressure in controlling its transfer dehydrogenation and the. corresponding effect on propylene-toethylene ratio during methanol-to-hydrocarbons catalysis on H-ZSM-5. J Catal. 356, 300-306 (2017).

21. Müller, S. et al. Coke formation and deactivation pathways on H-ZSM-5 in the conversion of methanol to olefins. J. Catal. 325, 48-59 (2015).

22. Liu, Z. H., Dong, X. L., Liu, X. \& Han, Y. Oxygen-containing coke species in zeolite-catalyzed conversion of methanol to hydrocarbons. Catal. Sci. Technol. 6, 8157-8165 (2016).

23. Zhao, X. B. et al. Investigation of methanol conversion over high-Si beta zeolites and the reaction mechanism of their high propene selectivity. Catal. Sci. Technol. 7, 5882-5892 (2017).

24. Müller, S. et al. Hydrogen transfer pathways during zeolite catalyzed methanol conversion to hydrocarbons. J. Am. Chem. Soc. 138, 15994-16003 (2016).

25. Martinez-Espin, J. S. et al. Benzene co-reaction with methanol and dimethyl ether over zeolite and zeotype catalysts: evidence of parallel reaction paths to toluene and diphenylmethane. J. Catal. 349, 136-148 (2017).

26. Hwang, A., Kumar, M., Rimer, J. D. \& Bhan, A. Implications of methanol disproportionation on catalyst lifetime for methanol-to-olefins conversion by HSSZ-13. J. Catal. 346, 154-160 (2017).

27. Hwang, A. \& Bhan, A. Bifunctional strategy coupling Y2O3-catalyzed alkanal decomposition with methanol-to-olefins catalysis for enhanced lifetime. ACS Catal. 7, 4417-4422 (2017).

28. $\mathrm{Wu}, \mathrm{X}$. Q. et al. Direct mechanism of the first carbon-carbon bond formation in the methanol-to-hydrocarbons process. Angew. Chem. Int. Ed. 56, 9039-9043 (2017).

29. $\mathrm{Wu}, \mathrm{X}$. et al. Evolution of $\mathrm{C}-\mathrm{C}$ bond formation in the methanol-to-olefins process: from direct coupling to autocatalysis. ACS Catal. 8, 7356-7361 (2018).

30. Forester, T. R. \& Howe, R. F. In situ FTIR studies of methanol and dimethyl ether in ZSM-5. J. Am. Chem. Soc. 109, 5076-5082 (1987).

31. Kresnawahjuesa, O., Gorte, R. J. \& White, D. Characterization of acylating intermediates formed on H-ZSM-5. J. Mol. Catal. A 208, 175-185 (2004).

32. Chen, X. Y., Neidig, M. L., Tuinstra, R. \& Malek, A. Direct observation of acetyl group formation from the reaction of $\mathrm{CO}$ with methylated H-MOR by in situ diffuse reflectance infrared spectroscopy. J. Phys. Chem. Lett. 1, 3012-3015 (2010).

33. Celik, F. E., Kim, T., Mlinar, A. N. \& Bell, A. T. An investigation into the mechanism and kinetics of dimethoxymethane carbonylation over FAU and MFI zeolites. J. Catal. 274, 150-162 (2010).

34. Cheung, P., Bhan, A., Sunley, G. J., Law, D. J. \& Iglesia, E. Site requirements and elementary steps in dimethyl ether carbonylation catalyzed by acidic zeolites. J. Catal. 245, 110-123 (2007).
35. Chowdhury, A. D. et al. Initial Carbon-carbon bond formation during the early stages of the methanol-to-olefin process proven by zeolite-trapped acetate and methyl acetate. Angew. Chem. Int. Ed. 55, 15840-15845 (2016).

36. Chowdhury, A. D. et al. Bridging the gap between the direct and hydrocarbon pool mechanisms of the methanol-to-hydrocarbons process. Angew. Chem. Int. Ed. 57, 8095-8099 (2018).

37. Plessow, P. N. \& Studt, F. Theoretical insights into the effect of the framework on the initiation mechanism of the MTO process. Catal. Lett. 148, 1246-1253 (2018).

38. Plessow, P. N. \& Studt, F. Unraveling the mechanism of the initiation reaction of the methanol to olefins process using ab initio and DFT calculations. ACS Catal. 7, 7987-7994 (2017).

39. Morooka, S., Matubayasi, N. \& Nakahara, M. Kinetic study on disproportionations of $\mathrm{C} 1$ aldehydes in supercritical water: Methanol from formaldehyde and formic acid. J. Phys. Chem. A 111, 2697-2705 (2007).

40. Wang, A. L. et al. Aldol condensation of acetic acid with formaldehyde to acrylic acid over $\mathrm{Cs}(\mathrm{Ce}, \mathrm{Nd}) \mathrm{VPO} / \mathrm{SiO} 2$ catalyst. RSC Adv. 7, 48475-48485 (2017).

41. HouŽViČKa, J. \& Ponec, V. Skeletal Isomerization ofn-Butene. Catal. Rev. 39, 319-344 (1997).

42. Klepel, O. Oligomerization as an important step and side reaction for skeletal isomerization of linear butenes on H-ZSM-5. Appl. Catal. 255, 349-354 (2003).

43. Ong, L. H., Domok, M., Olindo, R., van Veen, A. C. \& Lercher, J. A. Dealumination of HZSM-5 via steam-treatment. Microporous Mesoporous Mater. 164, 9-20 (2012).

44. Nashi, T. The colorimetric estimation of formaldehyde by means of the Hantzsch reaction. Biochem. J. 55, 416-421 (1953).

\section{Acknowledgements}

We acknowledge the support of the Bavarian Ministry of Economic Affairs and Media, Energy and Technology and Clariant Produkte (Deutschland) GmbH. S.M. is thankful to Elisabeth Hanrieder for helpful discussions. Y.L. and F.M.K. are thankful to Manuel Wagenhofer for his advice on ${ }^{13} \mathrm{C}$ quantification.

\section{Author contributions}

Y.L., M.T., M.S.-S. and J.A.L. conceived the research; Y.L. prepared the catalysts, performed the surface reactions, collected infrared spectra and analyzed the cokes; F.M.K did the quantification of $\mathrm{HCHO}$, the deactivation test and the ${ }^{13} \mathrm{C}-\mathrm{HCHO}$ cofeeding and tracing experiments; F.M.K., S.M. and M.E. carried out the catalytic reactions and analyzed the conversion and product selectivity. The manuscript was written through contributions of all authors. All authors have given approval to the final version of the manuscript.

\section{Additional information}

Supplementary Information accompanies this paper at https://doi.org/10.1038/s41467 019-09449-7.

Competing interests: The authors declare no competing interests.

Reprints and permission information is available online at http://npg.nature.com/ reprintsandpermissions/

Journal Peer Review Information: Nature Communications thanks Yu Han, Zhongmin Liu, and other anonymous reviewer(s) for their contribution to the peer review of this work.

Publisher's note: Springer Nature remains neutral with regard to jurisdictional claims in published maps and institutional affiliations.

Open Access This article is licensed under a Creative Commons Attribution 4.0 International License, which permits use, sharing, adaptation, distribution and reproduction in any medium or format, as long as you give appropriate credit to the original author(s) and the source, provide a link to the Creative Commons license, and indicate if changes were made. The images or other third party material in this article are included in the article's Creative Commons license, unless indicated otherwise in a credit line to the material. If material is not included in the article's Creative Commons license and your intended use is not permitted by statutory regulation or exceeds the permitted use, you will need to obtain permission directly from the copyright holder. To view a copy of this license, visit http://creativecommons.org/ licenses/by/4.0/

(c) The Author(s) 2019 